\title{
In situ studies of algal biomass in relation to physicochemical characteristics of the Salt Plains National Wildlife Refuge, Oklahoma, USA
}

\author{
Kelly M Major*1, Andrea E Kirkwood ${ }^{2}$, Clinton S Major ${ }^{1}$, John W McCreadie ${ }^{1}$ \\ and William J Henley²
}

Address: ${ }^{1}$ Department of Biological Sciences, University of South Alabama, Mobile, AL 36688 USA and ${ }^{2}$ Department of Botany, Oklahoma State University, Stillwater, OK 75078 USA

Email: Kelly M Major* - kmajor@usouthal.edu; Andrea E Kirkwood - akirkwoo@ucalgary.ca; Clinton S Major - smajor@usouthal.edu; JohnW McCreadie - jmccread@jaguar1.usouthal.edu; William J Henley - henley@okstate.edu

* Corresponding author

Published: 15 December 2005

Saline Systems 2005, I:II doi:10.1186/1746-1448-I-II

This article is available from: http://www.salinesystems.org/content/I/I/II

(C) 2005 Major et al; licensee BioMed Central Ltd.

This is an Open Access article distributed under the terms of the Creative Commons Attribution License (http://creativecommons.org/licenses/by/2.0), which permits unrestricted use, distribution, and reproduction in any medium, provided the original work is properly cited.

\begin{abstract}
This is the first in a series of experiments designed to characterize the Salt Plains National Wildlife Refuge (SPNWR) ecosystem in northwestern Oklahoma and to catalogue its microbial inhabitants. The SPNWR is the remnant of an ancient ocean, encompassing $\sim 65 \mathrm{~km}^{2}$ of variably hypersaline flat land, fed by tributaries of the Arkansas River. Relative algal biomass (i.e., chlorophyll concentrations attributed to Chlorophyll-a-containing oxygenic phototrophs) and physical and chemical parameters were monitored at three permanent stations for a one-year period (July 2000 to July 200I) using a nested block design. Salient features of the flats include annual air temperatures that ranged from -10 to $40^{\circ} \mathrm{C}$, and similar to other arid/semi-arid environments, 15-20-degree daily swings were common. Shade is absent from the flats system; intense irradiance and high temperatures (air and sediment surface) resulted in low water availability across the SPNWR, with levels of only ca. $15 \%$ at the sediment surface. Moreover, moderate daily winds were constant (ca. 8-12 $\mathrm{km} \mathrm{h}^{-1}$ ), sometimes achieving maximum speeds of up to $137 \mathrm{~km} \mathrm{~h}^{-1}$. Typical of freshwater systems, orthophosphate $\left(\mathrm{PO}_{4}{ }^{3-}\right)$ concentrations were low, ranging from 0.04 to $<1 \mu \mathrm{M}$; dissolved inorganic nitrogen levels were high, but spatially variable, ranging from ca. $250-600 \mu \mathrm{M}\left(\mathrm{NO}_{3}{ }^{-}+\right.$ $\left.\mathrm{NO}_{2}^{-}\right)$and 4-166 $\mu \mathrm{M}\left(\mathrm{NH}_{4}^{+}\right)$. Phototroph abundance was likely tied to nutrient availability, with high-nutrient sites exhibiting high Chl-a levels (ca. $1.46 \mathrm{mg} \mathrm{m}^{-2}$ ). Despite these harsh conditions, the phototrophic microbial community was unexpectedly diverse. Preliminary attempts to isolate and identify oxygenic phototrophs from SPNWR water and soil samples yielded 47 species from 20 taxa and 3 divisions. Our data indicate that highly variable, extreme environments might support phototrophic microbial communities characterized by higher species diversity than previously assumed.
\end{abstract}

\section{Background}

Relatively few microbial communities in hypersaline ecosystems, i.e., those with salinities consistently greater than that of seawater (35 psu), have been described in detail. Most investigations have focused on coastal salterns [24] and sabkhas $[6,7]$, or inland, chronically hypersaline lakes 
Table I: Climatological data from July 2000 through July 200 I for Cherokee, Oklahoma.

\begin{tabular}{|c|c|c|c|c|c|c|c|}
\hline \multirow{2}{*}{$\begin{array}{l}\text { Month } \\
2000-2001\end{array}$} & \multirow[b]{2}{*}{$\min$} & \multicolumn{2}{|c|}{ Temperature $\left({ }^{\circ} \mathrm{C}\right)$} & \multirow{2}{*}{$\begin{array}{l}\text { Rainfall (cm) } \\
\text { monthly total }\end{array}$} & \multicolumn{2}{|c|}{ Wind Speed $\left(\mathrm{km} \mathrm{h}^{-1}\right)$} & \multirow{2}{*}{$\frac{\text { Solar Radiation }}{{ }_{\text {mean }}}$} \\
\hline & & $\max$ & mean & & $\max$ & mean & \\
\hline Jul & 21.1 & 35.0 & 27.9 & 5.33 & 137.4 & 16.3 & 27.07 \\
\hline Aug & 22.8 & 39.4 & 31.1 & 0.51 & 54.1 & 16.6 & 25.05 \\
\hline Sep & 15.6 & 33.3 & 24.7 & 0 & 60.3 & 17.5 & 21.16 \\
\hline Oct & 11.7 & 22.8 & 17.0 & 18.03 & 73.5 & 15.3 & 12.96 \\
\hline Nov & 0 & 11.1 & 4.8 & 3.30 & 63.4 & 12.7 & 9.99 \\
\hline Dec & -7.2 & 2.8 & -2.3 & 1.78 & 79.5 & 13.4 & 8.99 \\
\hline Jan & -3.3 & 6.7 & 1.2 & 1.78 & 78.8 & 13.2 & 9.87 \\
\hline Feb & -2.8 & 8.3 & 2.4 & 8.38 & 81.7 & 14.5 & 9.92 \\
\hline Mar & 1.7 & 12.8 & 6.9 & 6.10 & 85.8 & 12.1 & 15.26 \\
\hline Apr & 8.9 & 23.3 & 16.7 & 1.02 & 100.2 & 18.5 & 20.89 \\
\hline May & 13.9 & 27.2 & 20.6 & 6.10 & 100.6 & 14.6 & 24.20 \\
\hline Jun & 18.9 & 33.3 & 26.1 & 6.60 & 98.1 & 18.5 & 27.99 \\
\hline Jul & 24.4 & 39.4 & 32.0 & 0.25 & 67.4 & 18.0 & 27.49 \\
\hline
\end{tabular}

(MESONET: The Oklahoma Climatological Survey)

such as the Dead Sea [17], Great Salt Lake [22] and Mono Lake [13]. Moreover, such studies have targeted planktonic and/or submerged benthic microbial mat communities that tend to be persistent and are millimeters to centimeters in thickness.

In contrast, the Salt Plains National Wildlife Refuge (SPNWR) in northwest Oklahoma, U.S.A. features extensive subaerial flats that are permanently moistened by hypersaline groundwater seepage. We would characterize this habitat as athalassic [12] because, although the salt source exists as buried Permian marine deposits, there is no geologically recent connection to any marine system. The nearest contemporary marine system is the Gulf of Mexico at a distance of $900 \mathrm{~km}$. The SPNWR flats generally lack visible photoautotroph biomass, yet we have been able to detect chlorophyll and isolate viable oxygenic phototrophs from nearly every soil and water sample collected.

Herbst [12] divides saline systems into four categories based on axes of habitat stability and salinity stress: stable lakes of low salinity, stable lakes of moderate to high salinity, temporary lakes of low to moderate salinity and extreme ephemeral hypersaline waters. The last of these appears to approximate the condition of the SPNWR flats, however, the reported dominance of microbial halophiles in such habitats does not adequately describe the broad range of salinity tolerances among the many taxa we have isolated to date [4, Kirkwood \& Henley, submitted]. Thus, the SPNWR, a semi-terrestrial ecotone, appears to be different from any hypersaline microbial habitat studied to date. In this paper, we report on the physicochemical conditions of the SPNWR ecosystem and relate them to temporal and spatial variation in chlorophyll concentrations (i.e., approximate estimates of biomass attributed to all
Chlorophyll- $a$ containing oxygenic phototrophs) across the flats.

\section{Results}

\section{Climatological and soil temperature data}

The SPNWR can be characterized as a formidable habitat, particularly during the summer months. Climate data for the 2000-2001 study period indicate that phototrophic microbial inhabitants of the flats are subject to broad daily and seasonal swings in temperature, light and wind speed (Table 1). Average incident solar radiation levels were lowest in winter and highest in summer, ranging from $c a$. 9 to $28 \mathrm{MJ} \mathrm{m}^{-2}$. This difference was attributable to a combination of daylength and maximum midday solar flux, that were higher ( $\mathrm{ca} .53 \%$ and $76 \%$, respectively) on the June than the December solstice (data not shown). Average day/night temperatures exhibited the largest degree of variation in summer and early fall (July-September), resulting in ca. 15-degree differences between daytime and nighttime hours. Average daily air temperatures hovered around $30^{\circ} \mathrm{C}$ from July through September. In general, rainfall totals were lowest in summer and winter months, with maxima occurring in October 2000 $(18.03 \mathrm{~cm})$ and March, May and June of 2001 (>6 cm). Average daily winds were of moderate speeds and ranged from $\mathrm{ca}$. 12 to $19 \mathrm{~km} \mathrm{~h}^{-1}$ across the flats, with daily maxima ranging from 54 to $137 \mathrm{~km} \mathrm{~h}^{-1}$ (Table 1 ).

The modeled $\mathrm{T}_{\text {soil }}$ for June through September 2001 is shown in figure 2 . The median and maximum diel amplitudes of fluctuation in $\mathrm{T}_{\text {soil }}$ were 22.4 and $30.6^{\circ} \mathrm{C}$; only overcast days exhibited amplitudes $<15^{\circ} \mathrm{C}$. Frequency distributions $\left(5^{\circ} \mathrm{C}\right.$ intervals) of modeled $\mathrm{T}_{\text {soil }}$ (all values and daily maxima) are shown in figure 3 . The median predicted $\mathrm{T}_{\text {soil }}$ for these four months was $30.6^{\circ} \mathrm{C}$, and $22 \%$ of the values exceeded $40^{\circ} \mathrm{C}$. Daily maxima $\mathrm{T}_{\text {soil }}$ were 


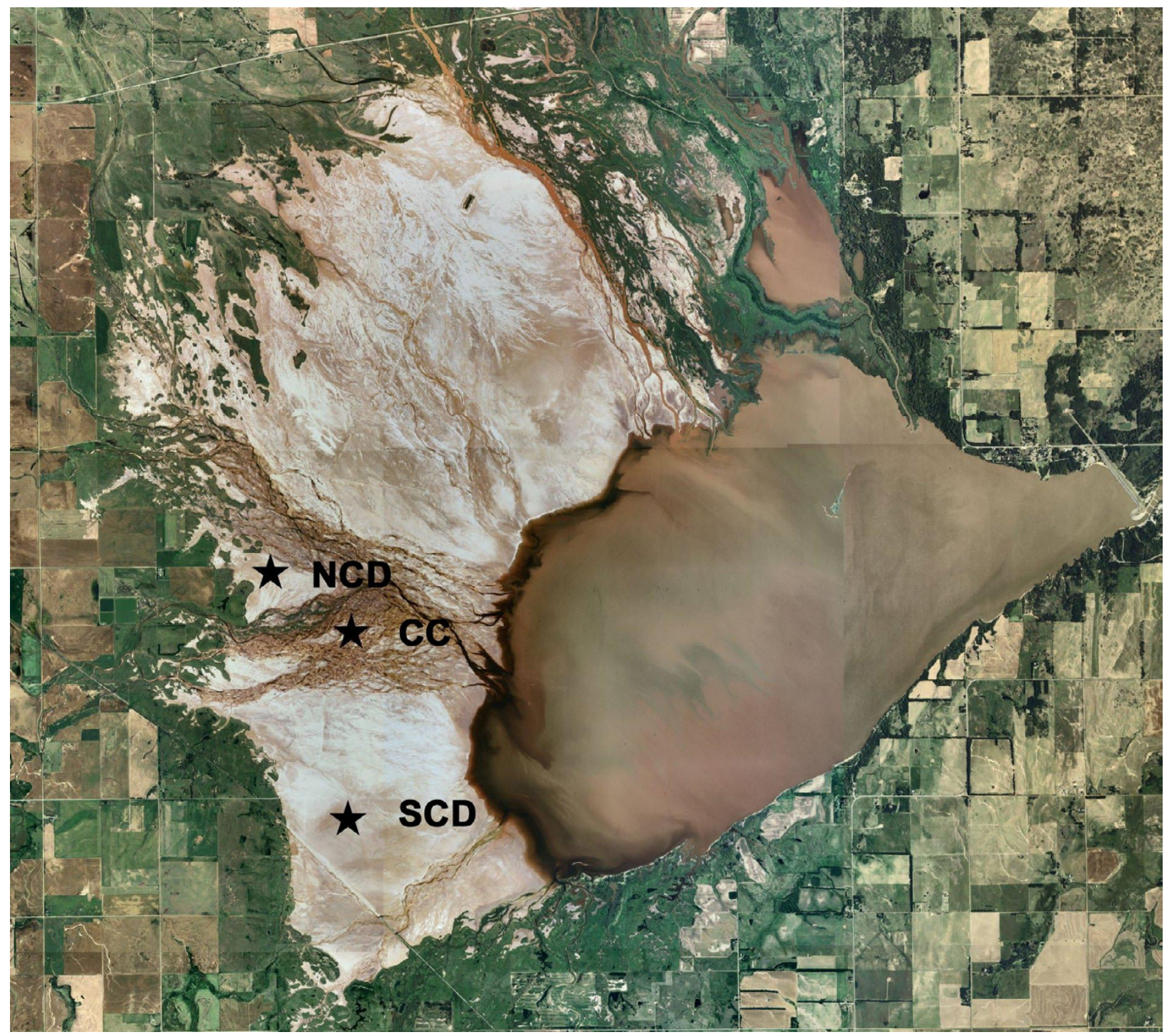

Figure I

Aerial view of the Salt Plains National Wildlife Refuge (SPNWR) depicting tributaries of the Arkansas River, the reservoir and salt flats. Labels denote North Crystal Dig (NCD), Clay Creek (CC) and South Crystal Dig (SCD) sampling stations. (This image was extracted from the 2003 NAIP aerial image database (Alfalfa Co., OK); http://www2.ocgi.okstate.edu/2003imgI/)

skewed, with approximately $80 \%, 51 \%$ and $20 \%$ of the days reaching at least 40,45 and $50^{\circ} \mathrm{C}$, respectively (Fig. 3). In July and August only, predicted maximum $\mathrm{T}_{\text {soil }}$ exceeded $45^{\circ} \mathrm{C}$ on 53 days $(85 \%)$ and $50^{\circ} \mathrm{C}$ on 24 days (39\%). The highest modeled $\mathrm{T}_{\text {soil }}$ was $53^{\circ} \mathrm{C}$, whereas, the observed maximum was $55.5^{\circ} \mathrm{C}$ on two days in early August. Taken together, the high degree of both daily and seasonal variability in air/soil temperature, light and wind speed represent what might be defined as the most extreme of the extreme environments (i.e., an environment characterized by high variability and multiple stressors).

\section{Algal diversity and biomass}

The SPNWR supports a surprisingly diverse phototrophic microbial community. To date, 47 species of oxygenic phototrophs from 20 taxa and 3 divisions (Chlorophyta, Cyanophyta and Bacillariophyta) have been isolated and identified from SPNWR soil and water samples (Table 2). The majority of species identified (62\%) belong to the prokaryotic division of cyanophytes. Not unexpectedly, four green algal species belong to the halophilic genus, Dunaliella. However, unlike the salt-adapted organisms typical of high salinity environments, many of the salt 


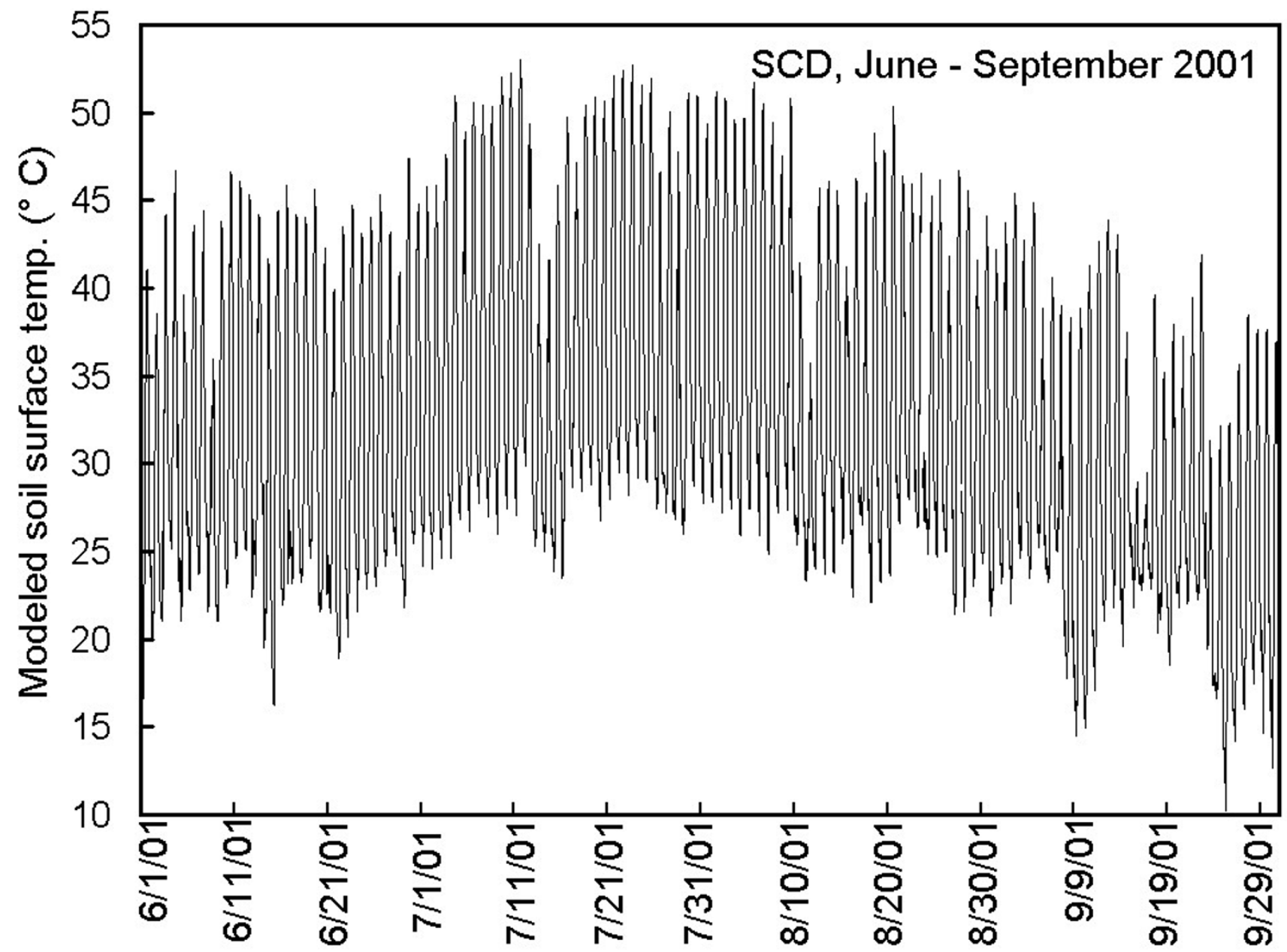

Figure 2

Modeled $\mathrm{T}_{\text {soil }}$ at SCD for June through September $200 \mathrm{I}$.

plains isolates exhibit a wide range of salt tolerance and some are able to grow in freshwater to at least $150 \mathrm{psu}$ (Kirkwood \& Henley, submitted).

Although no clear seasonal trends in algal biomass (i.e., biomass attributed to Chl-a-containing oxygenic phototrophs), nutrient concentration(s) or salinity were noted over the one-year study period, site-specific differences were evident. In terms of algal biomass, Chl- $a$ concentration was significantly lower at the CC site $(0.77 \mathrm{mg}$ $\mathrm{m}^{-2}$ ) relative to either the NCD or SCD sites ( $\mathrm{ca} .1 .46 \mathrm{mg}$ $\mathrm{m}^{-2} ; \mathrm{P}=<0.001 ;$ Fig. $4 \mathrm{~A}$ ). Nitrogen and phosphorus concentrations were higher at both the NCD and SCD sites when compared to those at the CC site (Fig. 4A,B). However, the dominant form of nitrogen varied with site such that NCD exhibited unusually high amounts of $\mathrm{NO}_{3}{ }^{+}$ $\mathrm{NO}_{2}{ }^{-}$, ranging in concentration from ca. 250 to nearly 600 $\mu \mathrm{M}$ (i.e., on average, almost 23 times more than $\mathrm{NO}_{3}{ }^{-}+$ $\mathrm{NO}_{2}$ - concentrations at either the SCD or CC sites), while the SCD site exhibited high concentrations of $\mathrm{NH}_{4}{ }^{+} \mathrm{up}$ to $166 \mu \mathrm{M}$ (Fig. 4A). The average $\mathrm{NH}_{4}{ }^{+}$concentrations were significantly lower at the CC and NCD sites (38.4 and 4.3 $\mu \mathrm{M}$, respectively) relative to those at the SCD site ( $\mathrm{P}=<$ 0.001 ). On the whole, soluble reactive phosphorus (SRP) availability was very low across the flats, ranging from 0.04 to $1.7 \mu \mathrm{M} ; \mathrm{PO}_{4}{ }^{3-}$ concentrations were often below the level of detection (i.e. $<0.01 \mu \mathrm{M}$ ). Levels of SRP were significantly lower at the CC site $(0.04 \mu \mathrm{M})$, with moderate and high levels noted for the SCD and NCD sites $(0.32$ and $0.85 \mu \mathrm{M}$, respectively; $\mathrm{P}=<0.001$; Fig. 4B). Thus, algal abundance (i.e., biomass of oxygenic phototrophs) appears to be driven by the availability of nitrogen (either in the form of $\mathrm{NH}_{4}{ }^{+}$or $\mathrm{NO}_{3}{ }^{-}+\mathrm{NO}_{2}^{-}$) in combination with relatively low concentrations of orthophosphate in the SPNWR system (Fig. 4A, B); statistical analyses did not support a clear correlation between $\mathrm{N}$ and $\mathrm{P}$ at the level of $\mathrm{P}<0.05$. Average ground water salinities ranged from 152 psu at SCD to 218 psu at CC, with that of NCD being mid- 


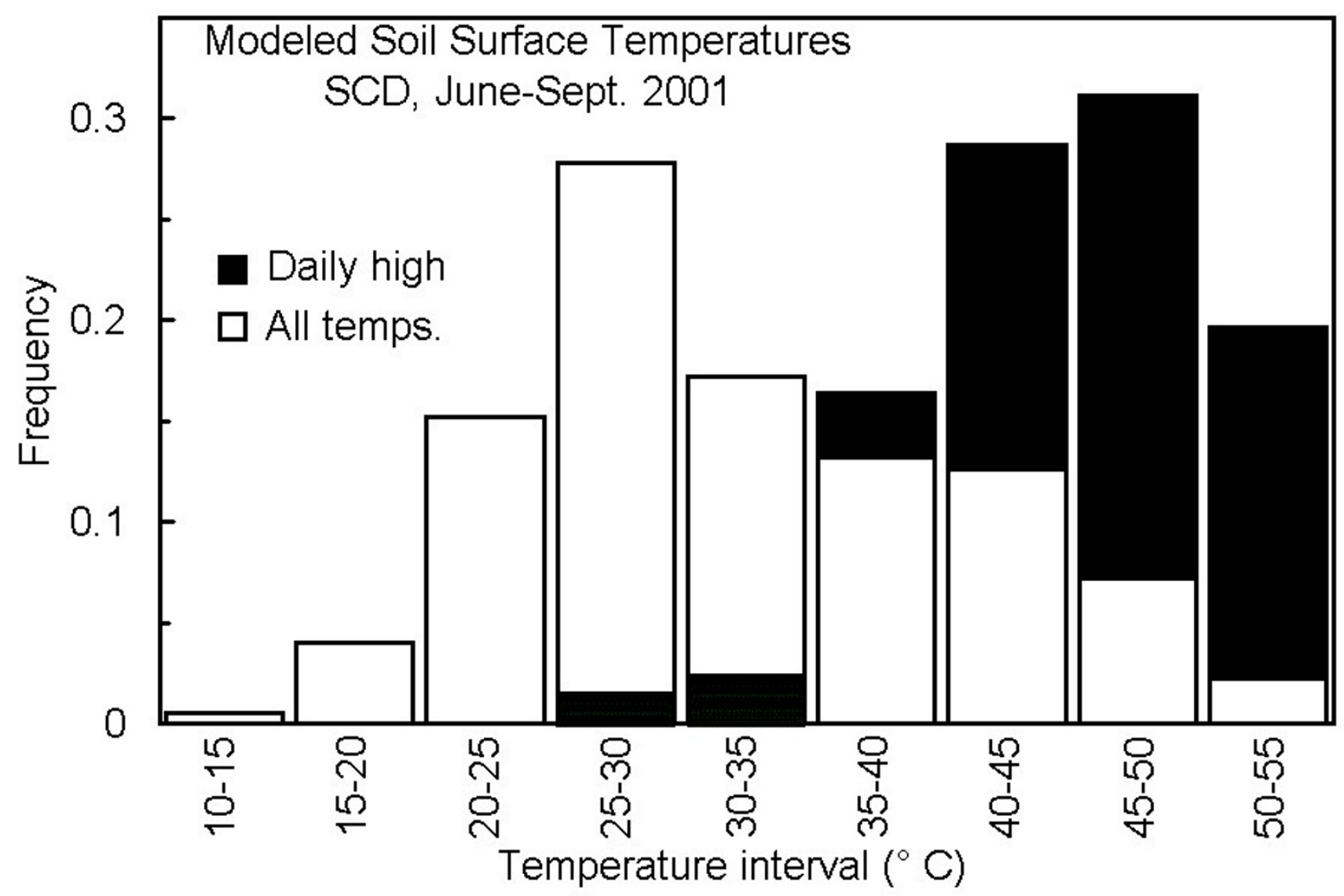

Figure 3

Frequency distributions $\left(5^{\circ} \mathrm{C}\right.$ intervals) of modeled SCD T $\mathrm{T}_{\text {soil }}$ (open bars) and daily maxima (filled bars) derived from figure 2.

range at $178 \mathrm{psu}$ (Fig. 4B). Although ground water salinity was significantly different among all sites $(\mathrm{P}=<0.001)$, soil moisture content at the sediment surface ( $c a .15 \%)$ did not vary among sites. Thus, it seems that nutrient availability is biologically more important than salt and/ or freshwater availability in this system. Despite the fact that Discriminant Function Analysis aligned CC and SCD together according to physical and chemical similarities (i.e., NCD was the outlier in this study; data not shown), algal biomass was high at stations with high $\mathrm{N}$ and $\mathrm{P}$ availability (i.e., NCD and SCD).

\section{Discussion}

To our knowledge, with the exception of some early qualitative descriptions of the plant communities of the region (e.g., Ortenburger and Bird [18]; Penfound [20] and Williams [30]), the first detailed description of the vegetation of the Salt Plains National Wildlife Refuge was provided by Baalman in 1965 [3]. Baalman documented the vegetational history and provided a higher plant species list for lands adjacent to the salt flats, with occasional anecdotal references to observations of cyanophytes. Similar to Baalman's work, Unger $[27,28]$ provided further documentation of the distribution of salt-tolerant higher plant species for the region as a function of soil characteristics, specifically, salinity. Since the completion of Unger's work in 1968, little else has been done to describe the salt flat ecosystem and, in particular, the unique phototrophic microbial communities that inhabit it. The present investigation provides the first detailed account of the physicochemical profile of the Oklahoma salt flat system and a preliminary sampling of photosynthetic microbes that inhabit the SPNWR.

Generally, high salinity is the norm in this ecosystem; low salinities coincide with rainfall as freshwater runs over the flats. In summer, this semi-arid ecosystem is hot and dry with salt crystals covering the sediment surface. It is not unusual for air temperatures to reach $40^{\circ} \mathrm{C}$. However, surface temperatures of the flats can be considerably higher or lower, depending upon solar heating and/or evaporative cooling. Furthermore, shade cover is absent from this 
Table 2: Summary of algal taxa isolated from the Salt Plains National Wildlife Refuge, Oklahoma.

\begin{tabular}{|c|c|c|c|c|c|c|}
\hline $\begin{array}{c}\text { Taxonomic } \\
\text { Division }\end{array}$ & Genus & No. of species & No. of isolates & Sample Types & $\begin{array}{l}\text { Isolation Salinities } \\
\text { (psu) }\end{array}$ & $\begin{array}{c}\text { Isolate } \\
\text { Distribution }\end{array}$ \\
\hline Chlorophyta & Dunaliella & 4 & 27 & soil, brine pools & 50,100 & $\begin{array}{l}\text { south, central, } \\
\text { north, }\end{array}$ \\
\hline Chlorophyta & Tetracystis & I & 1 & dried algal mat & 10 & central \\
\hline Chlorophyta & Tetraselmis & I & 1 & soil & 50 & central \\
\hline Cyanophyta & Aphanocapsa & I & I & dried algal mat & 10 & central \\
\hline Cyanophyta & Aphanothece & 2 & 2 & dried algal mat & 10 & central \\
\hline Cyanophyta & Cyanodictyon & I & 2 & soil, brine pools & 50 & central, north \\
\hline Cyanophyta & Geitlerinema & 7 & 31 & soil & $10,50,100$ & central \\
\hline Cyanophyta & Halomicronema & I & 1 & soil, algal mat & 50 & central \\
\hline Cyanophyta & Komvophoron & I & 2 & soil & 10 & central, south \\
\hline Cyanophyta & Leptolyngbya & I & 1 & soil & 50 & north \\
\hline Cyanophyta & Lyngbya & I & 2 & soil & 50 & central \\
\hline Cyanophyta & Phormidium & 8 & 27 & soil, algal mat & $10,50,100$ & central \\
\hline Cyanophyta & Pseudanabaena & 3 & 10 & soil & 10,50 & central \\
\hline Cyanophyta & Spirulina & I & 2 & pool sediment & 10,50 & central \\
\hline Cyanophyta & Tychonema & 2 & 3 & algal mat & 10 & central \\
\hline Bacillariophyta & Amphora & 4 & 38 & soil, brine pools & $10,50,100$ & $\begin{array}{l}\text { south, central, } \\
\text { north }\end{array}$ \\
\hline Bacillariophyta & Bacillaria & I & 1 & soil & 50 & central \\
\hline Bacillariophyta & Eucocconeis & 2 & 4 & soil & 10,50 & $\begin{array}{l}\text { south, central, } \\
\text { north }\end{array}$ \\
\hline Bacillariophyta & Navicula & 5 & 18 & soil & $10,50,100$ & $\begin{array}{l}\text { south, central, } \\
\text { north }\end{array}$ \\
\hline Bacillariophyta & Nitzschia & I & 3 & soil & 10,50 & central \\
\hline
\end{tabular}

system; organisms living on the flats are routinely exposed to full-sunlight and high levels of UV radiation. Thus, the SPNWR is an extreme environment with phototrophic microbial inhabitants that experience broad changes in temperature, salinity and irradiance that occur over daily, as well as, seasonal time scales. Moreover, the flats are heterogeneous, exhibiting spatial variability in salinity and nutrient availability, and hence, algal biomass. Such habitats, exhibiting major shifts between low and high extremes at regular, irregular and/or episodic intervals, are typically thought to be low in species diversity [8]. Contrary to previous studies addressing the effect of salinity on microbial community structure (e.g., Herbst and Blinn [11]), our data and those of Henley and Kirkwood (submitted) indicate that extreme habitats have the potential to support diverse phototrophic microbial communities. Similarly, Williams [31] also concluded that salinity is less important in determining biological community structure than once thought.

Many of the 47 species of oxygenic phototrophs listed herein are tolerant of broad ranges in salinity and temperature [10, Kirkwood and Henley, submitted, Major and Henley, in prep.]. Unlike true salt-adapted halophiles that thrive in high-salt environments, we suggest that the resident oxygenic phototrophs of the SPNWR fit the defini- tion of poikilotrophic microbes (sensu Gorbushina and Krumbein [8]). This is to say, that these phototrophs are adapted to extreme, often rapid, environmental change. On the whole, phototrophic microbes of the SPNWR tend to be present in low numbers and exhibit relatively slow growth rates [10, Major and Henley, in prep.], typical of microbes living in high-stress environments [8]. Nutrient availability (i.e., inorganic $\mathrm{N}$, regardless of form, and $\mathrm{PO}_{4}{ }^{3-}$ ) plays an important role in determining phototrophic microbial biomass distribution across the flats, with high nutrient concentrations having a positive influence on abundance. Because orthophosphate levels are very low, $\mathrm{P}$ is likely present in other, less biologically available forms. Low Chl-a concentrations associated with the Clay Creek site might be due to frequent freshwater inflow and, consequently, low nutrient availability and chronic scouring as this site resides in the center of the tributary system that flows across the reserve (Fig. 1).

As Williams [32] points out, saline habitats are important natural assets of considerable economic, ecologic, scientific and conservation value. Most notably, their unique physical and chemical characterization and distinctive biota set them apart from other aquatic and/or semiaquatic ecosystems. Extreme environments and the microbes that inhabit them offer invaluable insight into 

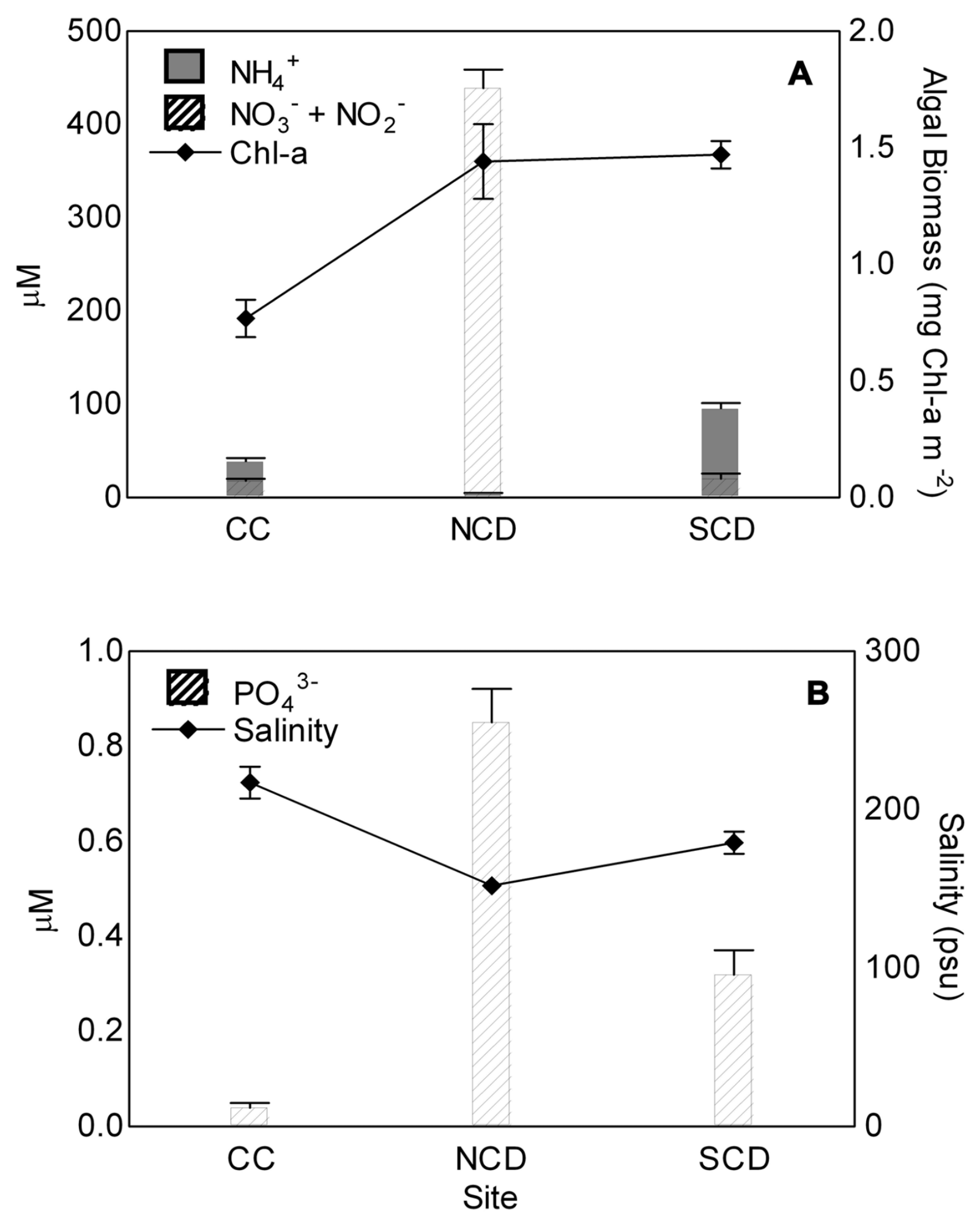

Figure 4

Variation in algal biomass as a function of $(\mathrm{A})$ nitrogen, $\mathrm{NH}_{4}{ }^{+}$and $\mathrm{NO}_{3}{ }^{-}+\mathrm{NO}_{2}^{-}$, (B) orthophosphate, $\mathrm{PO}_{4}{ }^{3-}$ and ground water salt concentration per site. Error bars denote $\mathrm{SE}$ of means. (Chl-a: $\mathrm{n}=108 ; \mathrm{NH}_{4}^{+}, \mathrm{NO}_{3}^{-}+\mathrm{NO}_{2}^{-}, \mathrm{PO}_{4}{ }^{3-}$ and salinity: $\mathrm{n}=34-36$ ) 
the fundamental physiological and ecological mechanisms of stress tolerance. Furthermore, such avenues of research might contribute to our understanding of early evolution and knowledge of agricultural practices in saline soils. Hypersaline microbial communities represent a largely untapped resource for potentially unique economically and scientifically useful model organisms.

\section{Methods \\ Study site}

The Salt Plains National Wildlife Refuge (SPNWR) resides in Alfalfa County in northwestern Oklahoma where salt flats cover approximately $64 \mathrm{~km}^{2}$ ([14]; Fig. 1). Farm and cattle ranching lands border the flats on three sides, while Great Salt Plains Reservoir is located at the southeastern edge of this system. Tributaries of the Arkansas River intermittently flow over the flats to feed the reservoir. Three permanent high-salinity sampling stations were established on the flats in July of 2000, each characterized by ground water salinities and soil moisture content of $c a$. $125-250$ psu and 15\%, respectively. Because this project was designed to specifically target extremophilic algae (i.e., oxygenic phototrophs), site selection was deliberately relegated to high salinity areas devoid of standing water. However, permanent sampling stations were then haphazardly placed within these high salinity areas. Sampling stations depicted in Figure 1 are North Crystal Dig (NCD; N 36 44'18" W 98 16'18"), Clay Creek (CC; N $36^{\circ} 43^{\prime} 51^{\prime \prime} \mathrm{W} 98^{\circ} 15^{\prime} 33^{\prime \prime}$ ) and South Crystal Dig (SCD; N $\left.36^{\circ} 42^{\prime} 26^{\prime \prime} \mathrm{W} 98^{\circ} 15^{\prime} 36^{\prime \prime}\right)$.

\section{Experimental design}

Temporal and spatial variation in algal biomass (i.e., Chlorophyll- $a$ concentration) and physicochemical characteristics across the Great Salt Plains ecosystem were determined using a nested block design. Each of the three sampling stations consisted of a $20 \times 10 \mathrm{~m}$ plot with three ground water wells (i.e., lysimeters) placed $10 \mathrm{~m}$ apart. Wells were constructed of 1.5 -m lengths of PVC, permanently sealed at the bottom with perforations along the length of the pipe to allow for collection of ground water; each well was buried to the water table at a sediment depth of approximately $1.0 \mathrm{~m}$ and capped at the sediment surface to avoid rainwater inundation. Water samples were obtained from each of the wells for salinity determination and nutrient analyses (see below). Triplicate sediment samples for chlorophyll and moisture content were always taken at 0,1 and $10 \mathrm{~m}$ distances in a west southwest direction from each well. All samples were collected monthly from July 2000 through July 2001.

\section{Sediment and ground water analyses}

Traditional limnological and biochemical assays were used to determine Chlorophyll-a (Chl- $a$ ) and nutrient concentrations in ground water and sediment samples.
Triplicate ground water samples were collected and analyzed for salt and nutrient content from each well at each station (NCD, CC and SCD; total $\mathrm{n}=9$ per station). To minimize degradation effects, samples for $\mathrm{NH}_{4}{ }^{+}$analysis were field-filtered (GF/F), placed on ice and immediately processed upon return to the laboratory as described by Parsons et al. [19]. Samples for $\mathrm{NO}_{2}{ }^{-}+\mathrm{NO}_{3}{ }^{-}$and orthophosphate $\left(\mathrm{PO}_{4}{ }^{3-}\right)$ were placed on ice, filtered and frozen upon return to the laboratory for later analysis. Concentrations of $\mathrm{NO}_{2}{ }^{-}+\mathrm{NO}_{3}{ }^{-}$and $\mathrm{PO}_{4}{ }^{3-}$ were determined using standard colorimetric techniques, designed for the chemical analysis of seawater [19] and the ascorbic acid method [9], respectively. Estimates of algal abundance were made using Chl- $a$ concentration as a proxy for relative biomass. Triplicate sediment cores $(2-\mathrm{cm}$ deep $\times 2.5$ $\mathrm{cm}$ diameter) were obtained at distances of 0,1 and $10 \mathrm{~m}$ from each well (total $\mathrm{n}=27$ per station) using a $60-\mathrm{mL}$ disposable syringe with its end removed, transferred to $50-\mathrm{mL}$ disposable centrifuge tubes and placed on ice. Samples were frozen upon return to the laboratory for later analysis. Sediment Chl extractions were performed in dim light by adding $8.0 \mathrm{~mL} \mathrm{~N}, \mathrm{~N}$-dimethyl formamide (DMF) to each sediment tube. Samples were vortexed daily and allowed to extract for 7-10 d. At the end of the extraction period, samples were centrifuged at 10,000 rpm for $20 \mathrm{~min}$ and spectrophotometrically analyzed using the equations of Porra et al. [21]. Sediment samples were also assayed to determine and correct for phaeopigment content using traditional fluorometric methods after Lorenzen [16]. Sediment cores (8-cm deep $\times 1.3-\mathrm{cm}$ diameter) were obtained using a $10-\mathrm{mL}$ disposable syringe with its end removed, transferred to $15-\mathrm{mL}$ pre-weighed disposable centrifuge tubes, placed on ice and frozen for later analysis. Moisture content of sediment-filled tubes was determined by slowly thawing, weighing ( $=$ wet weight) and drying sediment cores to a constant weight (= dry weight) for $7-10 \mathrm{~d}$ at $114^{\circ} \mathrm{C}$. Percent moisture was then estimated by subtracting sediment dry weight from wet weight to determine the original water weight of each sample and expressing it as a percentage of wet weight.

\section{Algal species isolation and identification}

Soil and ephemeral brine pool samples were collected from each of the three stations (i.e., NCD, CC and SCD; Fig. 1). Using the bottom of a sterile polystyrene petri dish (8.5-cm diam), 10 random cores from the top centimeter of salt plains soil were taken at each site and placed in a sterile plastic bag. Brine pool samples were collected in sterile Whirl-Pak ${ }^{\circledast}$ bags. All soil and brine pool samples were placed on ice in the field and transferred to a cold room facility $\left(\sim 8^{\circ} \mathrm{C}\right)$ until initial isolations were performed the next day. Parallel sub-samples of soil $(10 \mathrm{~g})$ were suspended in $75 \mathrm{~mL}$ of sterile liquid medium or directly plated ( $\sim 1 \mathrm{~g}$ soil) onto $1 \%$ agar plates $\left(\right.$ Bacto $\left.^{\mathrm{TM}}\right)$ made with SP medium [10]. To maximize the diversity of 
algae isolated, we used three media with salinities of 10 , 50 and 100 psu. Liquid and plate media with soil amendments were incubated under cool white light $(60 \mu \mathrm{mol}$ photons $\mathrm{m}^{-2} \mathrm{~s}^{-1}, 14: 10 \mathrm{~L} / \mathrm{D}$ ) at a temperature range of 25$28^{\circ} \mathrm{C}$. Once algal growth became visible (1-3 days), streak-plating was repeated to obtain unialgal cultures. Filamentous cyanobacteria were isolated using a phototactic purification method [25]. Using a Nikon E400 phase-contrast microscope, all algae were identified from live material to genus and when possible, species, under oil-immersion at $1000 \times$ magnification. Chlorophyte algae were identified using Tomas [26] and Wehr and Sheath [29], while diatoms were identified using Cox [5], Round et al. [23] and Tomas [26]. Cyanobacteria were identified using the taxonomic keys of Komarek and Anagnostidis [15], Anagnostidis and Komarek [2] and Abed et al. [1].

\section{Soil temperature data}

A Cox Tracer model CT1ED8 recording thermometer with an external sensor was used to measure soil surface temperature $\left(\mathrm{T}_{\text {soil }}\right)$ at SCD from 19 June through 22 July and 31 July through 27 September 2001. Temperatures were automatically recorded at $15-\mathrm{min}$ intervals. Air temperature $\left(\mathrm{T}_{\text {air }}{ }^{\circ} \mathrm{C}\right)$ at $1.5-\mathrm{m}$ height, solar radiation $\left(\mathrm{W} \mathrm{m}^{-2}\right)$ and wind speed $\left(\mathrm{m} \mathrm{s}^{-1}\right)$ at $10-\mathrm{m}$ height were obtained from the Cherokee Oklahoma Mesonet Station located approximately $9.5-\mathrm{km}$ northwest of SCD. The raw data were at 5min intervals, so 15 -min means were calculated for comparison to measured $\mathrm{T}_{\text {soil. }}$. Because the latter were available for only part of the summer, Mesonet data were used to model $\mathrm{T}_{\text {soil }}$ over a 4-month period (June - September). A direct multiple regression of the three Mesonet parameters explained $88.4 \%$ of the variance in measured $\mathrm{T}_{\text {soil }}$, and $90 \%$ of the residuals were within $\pm 5.2{ }^{\circ} \mathrm{C}$. The relationship was improved by using 1 -h sliding means of solar irradiance with a 3-h lag, which resulted in a subjectively acceptable model: predicted $\mathrm{T}_{\text {soil }}=0.924 \mathrm{~T}_{\text {air }}+$ 0.010 lagsolar -0.383 wind $+5.743\left(\mathrm{n}=8699, \mathrm{r}^{2}=0.937\right.$, $90 \%$ of residuals within $\pm 3.5^{\circ} \mathrm{C}$ ). $\mathrm{T}_{\text {air }}$ lagged solar and wind speed explained $85.4 \%, 7.5 \%$ and $0.8 \%$ of the variance in $\mathrm{T}_{\text {soil, }}$ respectively.

\section{Statistics}

Analyses were performed on biotic and abiotic data collected from the three permanent sampling stations (i.e., NCD, CC and SCD). All statistical tests were considered significant at the level of $\mathrm{P}<0.05$. Sampling dates with missing data were excluded to prevent bias. A one-way ANOVA was performed to test for mean differences among wells for each site. A Tukey pair-wise comparison for each well was conducted for each site between chlorophyll and wells to determine the relative order of variables.
Since samples from each well were potentially intercorrelated, a Principal Components Analysis (PCA) was conducted to summarize the variables into smaller, uncorrelated subsets. Stepwise regressions were conducted on 1) chlorophyll (response variable) versus each predictor variable for each site and 2) chlorophyll versus predictor variables and principal components. Data were log-transformed and a Discriminant Function Analysis was conducted to identify those sites that were most alike and to identify variables most useful for distinguishing among groups.

\section{Competing interests}

The author(s) declare that they have no competing interests.

\section{Authors' contributions}

KMM participated in the design and implementation of this study, collected field data and drafted the largest portion of this manuscript. AEK was responsible for isolation and identification of algal strains and drafted a portion of this manuscript. CSM and JWM performed statistical analyses and drafted a portion of this manuscript. WJH conceived of this study, participated in its design and coordination, contributed soil temperature data and drafted a portion of this manuscript. All authors read and approved this final manuscript.

\section{Acknowledgements}

The authors thank three anonymous reviewers for their constructive criticism on an earlier version of this manuscript, as well as, Daniel Ratcliff, Andrew Potter and Marga Mlenek for their assistance with field work and data collection. Thanks also to Mr. Jon Brock and Mr. Ron Sheppard of the US Fish and Wildlife Service and the SPNWR staff for their generous logistical support. Weather data were provided courtesy of the Okalahoma Mesonet, a cooperative venture of Oklahoma State University and the University of Oklahoma, supported by Oklahoma taxpayers. Funding for this project was provided by the National Science Foundation LExEn grant MCB-9978203 and Microbial Observatories grant MCB-0I 32097 awarded to $\mathrm{WJH}$.

\section{References}

I. Abed RMM, Garcia-Pichel F, Hernández-Mariné M: Polyphasic characterization of benthic, moderately halophilic, moderately thermophilic cyanobacteria with very thin trichomes and the proposal of Halomicronemaexcentricum gen. nov., sp. nov. Arch Microbiol 2002, I 77:361-370.

2. Anagnostidis K, Komarek J: Modern approach to the classification system of cyanophytes. 3. Oscillatoriales. Arch Hydrobiol Suppl 1988, 80:327-472.

3. Baalman RJ: Vegetation of the Salt Plains National Wildlife Refuge, Jet, Oklahoma. In PhD Thesis University of Oklahoma, Norman, OK, USA; 1965.

4. Caton TM, Witte LR, Ngyuen HD, Buchheim JA, Buchheim MA, Schneegurt MA: Halotolerant aerobic heterotrophic bacteria from the Great Salt Plains of Oklahoma. Microb Ecol 2004, 48:449-462.

5. Cox EJ: Identification of freshwater diatoms from live material. London, UK: Chapman \& Hall; 1996.

6. Ehrlich A, Dor I: Photosynthetic microorganisms of the Gavish Sabkha. In Hypersaline Ecosystems: The Gavish Sabkha Edited by: Friedmann GM, Krumbein WE. Springer-Verlag, Berlin; I 985:296-32I. 
7. Gerdes G, Krumbein WE, Holtkamp E: Salinity and water activity related zonation of microbial communities and potential stromatolites of the Gavish Sabkha. In Hypersaline Ecosystems: The Gavish Sabkha Edited by: Friedmann GM, Krumbein WE. SpringerVerlag, Berlin; 1985:238-266.

8. Gorbushina AA, Krumbein WE: Poikilotrophic response of microorganisms to shifting alkalinity, salinity, temperature and water potential. In Microbiology and Biogeochemistry of Hypersaline Environments Edited by: Oren A. CRC Press, Boca Raton; 1999:75-86.

9. Greenberg AE, Clesceri LS, Eaton AD: Standard Methods for the Examination of Water and Wastewater Washington, DC: American Public Health Association; 1992.

10. Henley WJ, Major KM, Hironaka JL: Response to salinity and heat stress in two halotolerant chlorophyte algae. J Phycol 2002, 38:757-766.

II. Herbst DB, Blinn DW: Experimental mesocosm studies of salinity effects on the benthic algal community of a saline lake. J Phycol 1998, 34:772-778.

12. Herbst DB: Gradients of salinity stress, environmental stability and water chemistry as a template for defining habitat types and physiological strategies in inland salt waters. Hydrobiologia 200I, 466:209-2I9.

13. Hollibaugh JT, Wong PS, Bano N, Pak SK, Prager EM, Orrego C: Stratification of microbial assemblages in Mono Lake, California, and response to a mixing event. Hydrobiologia 200I, 466:45-60.

14. Johnson KS: Guidebook for geological field trips in Oklahoma. Book II: Northwest Oklahoma. Oklahoma Geological Survey, Norman 1972.

15. Komarek J, Anagnostidis K: Modern approach to the classification system of cyanophytes. 2. Chroococcales. Arch Hydrobiol Suppl 1986, 73:157-226.

16. Lorenzen Cl: Determination of chlorophyll and phaeopigments: spectrophotometric equations. Limnol Oceanogr 1967, 1 2:343-346.

17. Oren A: Microbiological studies in the Dead Sea: future challenges toward the understanding of life at the limit of salt concentrations. Hydrobiologia 1999, 405: I-9.

18. Ortenburger Al, Bird RD: The ecology of the western Oklahoma salt plains. Univ Okla Biol Survey 1933, 5:49-64.

19. Parsons TR, Maita Y, Lalli CM: A manual of chemical and biological methods for seawater analysis. New York: Pergamon Press; 1984.

20. Penfound WT: Plant communities of Oklahoma lakes. Ecology 1953, 34:56|-583.

21. Porra RJ, Thompson WA, Kriedemann PE: Determination of accurate extinction coefficients and simultaneous equations for assaying chlorophylls $a$ and $b$ extracted with four different solvents: verification of the concentration of chlorophyll standards by atomic absorption spectroscopy. Biochim Bioiphys Acta 1989, 975:384-394.

22. Post F]: The microbial ecology of the Great Salt Lake. Microb Ecol 1977, 3:143-165.

23. Round FE, Crawford RM, Mann DG: The diatoms. Cambridge, UK: Cambridge University Press; 1990.

24. Spear JR, Ley RE, Berger $A B$, Pace NR: Complexity in natural microbial ecosystems: The Guerrero Negro experience. Biol Bull 2003, 204:I68-I73.

25. Stanier RY, Kunisawa R, Mandel M, Cohen-Bazire G: Purification and properties of unicellular blue-green algae (Order Chroococcales). Bacteriol Rev 197I, 35: I7I-205.

26. Tomas CR.: Identifying Marine Phytoplankton. New York: Academic Press; 1997.

27. Ungar IA: Salt tolerance of plants growing in saline areas of Kansas and Oklahoma. Ecology 1966, 47(I): 154-155.

28. Ungar IA: Species-soil relationships on the Great Salt Plains of Northern Oklahoma. Amer Midl Natur 1968, 80(2):392-406.

29. Wehr JD, Sheath RG: Freshwater algae of North America: Ecology and Classification. New York: Academic Press; 2003.

30. Williams CR: Mammalian ecology of the Great Slat Plains Wildlife Refuge. In PhD Thesis University of Oklahoma, Norman, OK, USA; 1954.

31. Williams WD: Salinity as a determinant of the structure of biological communities in salt lakes. Hydrobiologia 1998, 38I: $|9|-201$.
32. Williams WD: Environmental threats to salt lakes and the likely status of inland saline ecosystems 2025. Environmental Conservation 2002, 29(2): I54-167.
Publish with Biomed Central and every scientist can read your work free of charge

"BioMed Central will be the most significant development for disseminating the results of biomedical research in our lifetime. "

Sir Paul Nurse, Cancer Research UK

Your research papers will be:

- available free of charge to the entire biomedical community

- peer reviewed and published immediately upon acceptance

- cited in PubMed and archived on PubMed Central

- yours - you keep the copyright 